\title{
Effectiveness of Differentiated Instruction on Primary School Students' English Reading Comprehension Achievement
}

\author{
Ibrahim Suleiman Ibrahim Magableh \\ USM, Universiti Sains Malaysia \\ Malaysia \\ Amelia Abdullah \\ USM, Universiti Sains Malaysia \\ Malaysia
}

\begin{abstract}
This study explores the effectiveness of differentiated instruction strategies on EFL students' English reading comprehension accomplishment on the fundamental level in Jordan. Four classes of $(n=118)$ students of the primary level from 4 different schools were selected. Two levels of grade 4 students $(n=59)$ and two levels of grade 5 $(n=59)$ were divided into two control and two experimental groups. One level of $(n=30)$ students formed grade 5 experimental groups, and one level of $(n=29)$ formed the control groups. Moreover, one level of $(n=30)$ students of grade 4 formed the experimental group, and one level of $(n=29)$ formed the control group. The teachers followed differentiated instruction strategies of flexible grouping, tiered instruction, and tiered assignments in the areas of content, process, and product to teach the experimental group. However, they followed the one-size-fits-all method to teach the control group. Results indicated that employing differentiated instruction was operational in improving EFL students' reading comprehension attainment for grades four and five Jordanian students. The experimental group statistically outperformed the control group. The finding showed that differentiated education reduced classroom diversity.
\end{abstract}

Keywords: differentiated instruction; reading comprehension; flexible grouping; one-size-fits-all; content

\section{Introduction}

Reading comprehension is a significant skill, and the development of this ability for EFL learners in EFL classes is significant because it influences students' achievement at all students' proficiency levels; it is essential to students' knowledge achievement (Ismail \& Al Allaq, 2019; Kent, 2005). However, teachers face a problem when teaching to a group of heterogeneous learners in 
the same classroom and want to address the diversity of individual learners (Kotob, \& Abadi, 2019). If teachers want to improve reading comprehension achievement for all students, teachers should implement instruction in a way that fulfills the individual needs of learners (Aliakbari \& Haghighi, 2014; Hawkins, Jones, \& Santi, 2019).

How can teachers deal with all the levels and students' diversity in the same classroom when following one-size-fits-all process? Tomlinson and Imbeau (2010) mentioned that the one-size-fits-all process should be vanished and ended. Tomlinson (2014) explained that this traditional method does not fulfill the academic needs of individual learners because it does not deal with individuals rather than the whole class. Teachers should plan the lessons to adjust them to learners instead of expecting to improve learners to the experiences (Corley, 2005; Mavidou, \& Kakana, 2019). Teachers should make sure that all learners in the classroom are both similarly served as well as equally valued. The one-size-fits-all process does not do that. However, differentiated instruction does. Mulder (2014) defines differentiated instruction as "an approach in which teachers modify and change their teaching to address the varied needs of individual learners and small groups of students to maximize the learning opportunity for each student in the classroom by using organized procedures" (p.10).

Heacox (2018) stated that distinguished instruction offers a variety of methods that provides support and supervision when learners are just starting to practice their instructional choices. Bondie, Dahnke, and Zusho (2019) explained that differentiated instruction allows teachers to plan strategically to meet individual needs where they are, and provide numerous techniques to understand, gain, and employ learning, unlike the one-size-fits-all. In discriminated learning, teachers need to modify teaching in the areas of content, procedure, product, and learning environment depending on students' readiness, interests, and learning profiles (Said \& Ehsan, 2019). The content is what students need to learn, and to the significant concepts, skills, and principals. Teachers modify the level of complexity using various educational procedures to deliver the content to meet students' diverse needs (Anstee, 2014). So, in this way, all learners grasp the same conceptions, skills, and principles but in different ways.

The process is the methods students are learning and the procedures the teachers are teaching (Tompkins, Campbell, Green, \& Smith, 2014). It refers to the ways the teachers prepare the content, and to the activities that help students to gain the concepts, the principles, and the skills intend to learn. Flexible grouping is the key to differentiate the process in which teachers arrange students by ability or proficiency level, interests, readiness, or learning profiles (Tomlinson, 2015). The product shows evidence of learning that demonstrates what students have learned. The outcome indicates whether the students have earned the concepts, the principles, and the skills and whether they apply them to solve problems. Various students can produce different outcomes based on their proficiency level, development, and learning styles (Tomlinson \& Imbeau, 2010). Students should get choices to demonstrate their learning, from written reports, oral presentations, drawing, group discussions, or play roles, and they can choose to work alone or in groups if they wish. The learning environment is the 
setting in which students are learning; it is the climate of the classroom. Teachers can vary seating, vary lighting, change places, form learning stations, set class rules, change furniture arrangement, as well as alter the procedures and the processes (Tomlinson, 2017).

Readiness refers to the students' level of knowledge, understanding, and the skills of particular learning (Graham, Borup, Pulham, \& Larsen, 2019; Tomlinson \& Imbeau, 2010). Prior to earning, life experiences, and students' attitudes toward schools influence readiness. So if readiness level varies, the complexity of work through tiered activities must differ as well (Sebihi, 2016). Interests stem from the topics that lead to curiosity and passion, which lead to devote students' time and effort to learn. When benefits are employed, students will be more engaged in learning. Finally, the learning profile is how learners learn the best. Differentiated instruction takes into consideration preferences for learning regarding intelligence preference, culture, and even gender. Teachers modify teaching using learning profiles by providing tasks that offer choices to master learning like videotapes, drawings, journals, presentations, role plays, projectbased learning, and oral explanations (Malacapay, 2019).

Reading comprehension in EFL classes is a challenging skill EFL learners face. English foreign language learners encounter many difficulties in gaining the reading comprehension skills easily (Kassem, 2020). Kassem explained that reading comprehension skills can be difficult to master for EFL learners. The problem statement stems from the fact that teachers in Jordan are applying the one-size-fits-all method to deal with the reading comprehension texts (Magableh \& Abdullah, 2019). Siam and Al-Natour (2016) found that in the majority of Jordanian public schools, Jordanian teachers employ the one-size-fits-all, and no differentiation takes place in EFL classes. Al Harafsheh (2016) mentioned that Jordanian teachers' methods of teaching do not inspire students to read, which eventually influences their reading comprehension performance. AlShoura (2017) stated that the Ministry of Education in Jordan provides full classroom inclusion to all students despite their proficiency level even to the particular extreme of Special Education Need (SEN) cases. In this way, all students feel that they are equally important and no separation to students regarding of proficiency level to take place. There are advantages of mixed-ability classrooms in Jordan. First, the SEN students feel that they are part of the community and no different classification happened to them. Moreover, mixed-ability classrooms save money and equipment (Siam and Al-Natour (2016). However, Magableh and Abdullah (2019) talked about some disadvantages like although students are in mixed-ability classrooms, they are being taught the same and no differentiation takes place. With this full inclusion in Jordanian classrooms, the one-size-fits-all method that deals with all students at the same time is no longer an appropriate way to deal with such classes. Therefore, it becomes an urgent need to use differentiated instruction to address this class diversity. Based on the idea that the amendment in the guidance and preparation might help students' English reading comprehension accomplishment and might correspond to students' needs, the researchers conducted this study to scrutinize the effectiveness of distinguished education in enhancing EFL students' English reading comprehension achievement in Jordan. 


\section{Literature Review}

Many studies and researches adopted differentiated instruction in language one context, but minimal studies investigated the effect of differentiated instruction in language two environments. Many studies investigated the talented, gifted, the struggling students, or the disabled students as the primary subjects of differentiated instruction. Still, very few took modified direction in mixed-ability EFL classrooms as their main subject. Recently, various studies explored differentiated instruction efficiency in different language skills like (Altin \& Savaculoglu, 2018; Davidsen, 2018; Förster, Kawohl \& Souvignier, 2018; Jefferson, Grant \& Sander, 2017; Kotob and Abadi 2019; Magableh \& Abdullah, 2019; Mavidou \& Kakana, 2019; Nino Santisteban, 2014; Pastein, 2017; Shaaunessy-Dedrick, Evan, Fevron, \& Lindo, 2015; Stavrou \& Koutselini, 2016; and Yousefi \& Bouyadi, 2016). Niño Santisteban (2014) investigated the effect of differentiated learning on literacy with struggling learners. The sample consisted of 15 Spanish speaking children taking English as a foreign language. Most of the students faced interrupted schoolings in Columbia because of many social factors. Researchers used differentiation in each classroom in both English and Spanish. The researcher used qualitative and quantitative measurements to reveal the results of the study. She used three tools of the research, survey, interview, and observation. The results showed that there was minimal effect of differentiation on writing and vocabulary. However, there was a meaningful influence on reading comprehension in inference, comparison, and contrast.

Shaunessy-Dedrick, Evan, Ferron, and Lindo (2015) inspected the effects of a modified reading approach on the $4^{\text {th }}$ grade students' English reading comprehension and their views toward reading. Eight primary schools in one district were randomly allocated to the investigation, which followed the Schoolwide Enrichment Model-Reading [SEM-R] and the borough curriculum. The control group studied the district reading curriculum only. Experimental group teachers applied SEM-R as supplemental material to the city curriculum for one school year, whereas comparison group teachers used the borough curriculum. Grounded on the reading comprehension post-tests scores $(n=358)$ and the reading survey $(n=429)$, no statistically meaningful differences in students' attitudes toward reading found. Still, modified curriculum students of the treatment group had significantly higher mean scores on the English reading comprehension post-test in comparison to the comparison group students.

Yousefi and Bonyadi (2016) investigated the result of modified learning on reading comprehension achievement on Iranian language two learners. The experimental group consisted of 30 respondents and the same number for the control group following a random sample distribution to gain the uniformity of the groups. Over twelve sessions, the experimental group developed modified learning strategies, while the control group studied traditionally. The researchers followed the pre-test/post-test reading comprehension as the key instrument for data collection. The findings indicated that the experimental groups' mean scores outperformed the control groups mean scores. The results showed that differentiated instruction enriched students' reading comprehension achievement. 
Jefferson, Grant, and Sander (2017), in a quasi-experimental design, searched the influence of separated instruction and intervention on reading fluency and reading comprehension. The sample involved 83 male and female grade 3 students divided into the two groups of the study. The researchers used a pretest/post-test methodology to collect data: over five months, the experimental group received differentiated reading comprehension materials. However, the control group received the core curriculum only. The findings showed that the learners who trained using separated materials through modified teaching strategies showed higher mean scores compared to those in the control group.

Altin and Saracaloğlu (2018) explored the effect of differentiated instruction enhanced with cultural, educational materials on English reading comprehension, vocabulary, and students' attitudes toward English lessons. Two levels of grade 7 students were randomly assigned to the two groups of the study. The researchers followed the quasi-experimental design in which a pre/post English reading comprehension achievement test was used to obtain the results of the investigation. Over six weeks, treatment teachers trained the experimental group on reading comprehension texts improved with educational materials following differentiated learning techniques. However, the comparison group studied the standard reading comprehension instruction for the same period. The results showed that differentiated instruction positively contributed to students' reading comprehension achievement and their views toward English learning.

Davidsen (2018) investigated the results of distinguished teaching on level 3 students' English reading comprehension. The study aimed to compare the differentiated instruction strategies to traditional teaching on grade three English reading comprehension achievement. The sample consisted of $1283^{\text {rd }}$ graders. The experimental group was 64 students educated with modified instruction, while the comparison group, which was 64 students, received a traditional education. This quasi-experimental study lasted a whole year to reveal the results, which showed that separated learning significantly improved the third-grade students' reading comprehension achievement.

Forster, Kawohl, and Souvignier (2018) investigated the effect of long term differentiated teaching on reading comprehension and on reading fluency. Twenty-eight third-grade students in Germany participated in both groups of study. The treatment group's instruction was modified on both reading comprehension and fluency, while the control group's teaching was not distinguished. The results showed that the treatment group considerably improved in comparison with the traditional group in terms of reading comprehension and reading fluency. The findings also showed that the belowaverage students got the maximum benefit.

Kotob and Abadi (2019) examined the effect of modified instruction of the below-average and the above-average learners on academic attainment in a mixed-ability classroom. The sample involved 20 students, ten below-average, and ten above-average. The researchers applied a pre/post-test to collect data quantitatively. They implemented differentiated education strategies on both groups as an intervention. The findings showed that the average score of the 
whole class was improved. Moreover, the results discovered a noticeable improvement in the below-average scores, while the mean score for the aboveaverage remains somehow relatively the same. Differentiated instruction, as shown from the findings, is a strategy with a significant influence on belowaverage students.

Magableh and Abdullah (2019) searched the effectiveness of differentiated instruction on reading comprehension through a mixed-method treatment in which the qualitative and quantitative methods were used to reveal the results of the study. The researchers used a pre/post English reading comprehension test and a semi-structured interview as the instruments of the research. The sample consisted of 55 grade 7 Jordanian students from two different levels in two different randomly selected schools. Twenty-eight students formed the experimental group, trained on reading comprehension through differentiated instruction, and 27 students formed the control group, studied standard reading comprehension texts using the one-size-fits-all method. This quasi-experimental study used differentiated education strategies of flexible grouping, categorized assignments, and tiered learning in the fields of content, methodology, and outcome over 12 weeks of treatment. The results revealed that modified teaching was robust in increasing reading comprehension and reducing classroom diversity.

Mavidou and Kakana (2019) examined the efficiency of differentiated instruction on children's reading achievement. This quasi-experimental study used pretest/post-test instruments to explore the results of differentiated instruction of three interventions, including curriculum adjustment and differentiated content. One hundred fifty-four kindergarten students participated in both groups. The investigational group consisted of 80 students from different schools to receive differentiated learning. The control group received conventional education and consisted of 74 students. The instruction of the experimental group was separated based on learners' readiness, interests and learning preferences. The content was also distinguished and tailored to children's proficiency level supported with tiered materials to suit the three ability levels of students, the above-average, the average, and the below-average. In contrast, instruction was not characterized for the control group. The process was differentiated by flexible grouping and, the product was distinguished by interests, readiness, and both together. The research findings showed a momentous positive difference between the two groups favoring the experimental group, which suggests that differentiated instruction developed students' achievements. Moreover, differentiation by interest proved to have the highest mean score among all other kinds of differentiated strategies.

Following the findings of the studies and the literature of differentiated instruction, the researchers hope that the results of the current study add valid and reliable data to the existing knowledge by providing information about the effectiveness of differentiated instruction on primary classes in Jordan concerning reading comprehension. The English language teachers in Jordan who are teaching in public schools can deal with students with different background knowledge, needs, interests, learning styles, and even struggling 
learners in one single classroom following differentiated learning. Jordanian classes contain above-average, average, below-average, over-achieved, and under-achieved learners. Yet whatever the teachers do to deliver instruction, the teachers can only fulfill the needs of some learners, but not all of them. Teachers need to be responsive to students' diverse academic needs (Hawkins, Jones, \& Santi, 2019). To deal with this diversity, the researchers decided to employ differentiated instruction strategies of flexible grouping, tiered instruction, and categorized assignments in the content, process, and product to investigate the effectiveness of differentiated instruction on reading comprehension in the Jordanian context. To pursue the aim of the research, the treatment will answer the following question:

Is there a difference in English reading comprehension achievement between the students exposed to differentiated instruction and those exposed to the one-size-fits-all method?

The researchers hypothesize the null hypothesis, which indicated that there is no statistically significant difference at $(\alpha<0.05)$ between the students exposed to differentiated instruction and those exposed to the one-size-fits-all method in English reading comprehension achievement.

\section{Methods}

\subsection{Design}

The researchers followed the quasi-experimental quantitative model in which the investigators use the pre-test/post-test two-group design to collect the data of the research. A pre-test was conducted at the inauguration of the treatment for both groups. After ten weeks of instruction, the post-test was conducted. The results were analyzed quantitatively. The design is as follows (Creswell, 2012):

$\begin{array}{lll}\mathrm{RXO}_{1} & \mathrm{X}_{1} & \mathrm{O}_{2}\end{array}$

$\mathrm{RCO}_{3} \mathrm{X}_{2} \quad \mathrm{O}_{4}$

$\mathrm{RX}$ refers to the random experimental group, $\mathrm{RC}$ for the random control group, $\mathrm{O}_{1}$ is the reading comprehension pre-test for the experimental group, $\mathrm{O}_{2}$ is the experimental group post-test, $\mathrm{O}_{3}$ the reading comprehension pre-test for the control group, and $\mathrm{O}_{4}$ is the control group post-test. The $\mathrm{X}_{1}$ is the experiment (differentiated instruction strategies), and $X_{2}$ is the one-size-fits-all teaching for the control group.

\subsection{Participants}

The sample of the study consisted of 118 participants. All participants were male students from the elementary levels of grade $4(n=59)$ and grade $5(N=59)$. Public schools in Jordan depend on separate education, which means that co-education does not exist in public schools. We have girls' schools and schools for boys. This is the reason why the researcher used male sample only. So, it would be easier for the researcher to conduct the research on male schools. Two classes of grade 4 and 2 types of grade 5, from 4 different schools in Irbid, Jordan, participated in 
the study. The investigators used the simple random sampling method to choose the four schools and the four levels of grades 4 and 5 . The four schools did not apply differentiated instruction before the experiment in a systematic way, and the whole class instruction is the dominant way of teaching. The participants were randomly distributed into the two groups of study, the experimental group, which involved the two levels of grades 4 and $5(N=60)$ students and were prepared using differentiated instruction strategies. The control group $(\mathrm{N}=58)$ students were distributed into two levels of grades 4 and 5 and received reading comprehension traditionally. Table 1 summarizes the participants' distribution in the study groups:

Table 1: The dissemination of participants in the study

\begin{tabular}{|c|c|c|c|}
\hline group & Grade 4 & Grade 5 & Total \\
\hline Experimental Group & 30 & 30 & 60 \\
\hline Control group & 29 & 29 & 58 \\
\hline Total & 59 & 59 & 118 \\
\hline
\end{tabular}

Furthermore, four competent teachers participated in the study from 4 different schools. Two experimental group teachers with 14 and 15 years teaching experience holding Bachelor degrees taught the treatment students. Besides, two teachers with 15 and 16 years of experience with an MA and a B.A degree instructed the control group. The experimental group teachers were asked to use differentiated instruction strategies. They were trained in six workshops before the beginning of the experiment to acquaint them with the research strategies and another five sessions during the investigation. However, the control group teachers were informed to use the traditional method only.

\subsection{Instrument}

Two pre-tests/ post-tests were used as the main instruments of the current research. The treatment teachers administered the reading comprehension pretest for the two groups at the start of the study. A reading comprehension pretest for class 4, and another pre-test for grade 5 was administered at the onset of the research. The central goal of the pre-tests is to determine the level of the students so that flexible grouping, tiered instruction, and tiered assignments are employed. However, the post-test aims to investigate the effect of the treatment on the experimental and the control groups. The reading comprehension tests consisted of two familiar passages for each grade level with 25 multiple-choice items with 2 points for each item. Students are acquainted with such types of texts because teachers depend on similar tests in regular classes. The test is designed like this so that students are consistent with what they are used to. The assay is out of 50, and the time for completing it is 45 minutes. Before administering the tests, the researchers ensure their validity. Both assays for grades 4 and 5 were given to a board of two EFL instructors in Yarmouk University, two English supervisors in Irbid district of education, and four English teachers who are teaching grades 4 and 5. The board was kindly asked to express opinions on the content of the tests, complexity, timing, grammar, and questions' relatedness to content. The researchers followed the panels' recommendations and made the amendments accordingly. 
To ensure reliability, the researchers followed the test/retest method. The test was steered to a whole part of class 4 consisted of 26 students from the community but outside the sample and class 5 test was driven to a whole part of grade 5 included 25 students from the same city but outside the study sample. The duration between the test retest was two weeks. The correlation coefficient was found to be 0.90 for grade 4 and 0.86 for grade 5 . The correlation coefficient lies between -1 and 1 and is considered to be acceptable if it is 0.6 and above (Pallant, 2005). The researchers found the correlation coefficient for the two times of the test robust and adequate to conduct this research since both are above 0.8 .

\subsection{Materials}

The main course books were Action Pack 4 for grade 4 and Action Pack 5 for grade 5. Action Pack is a series of texts taught in the Ministry of Education in Jordan from grade 1 to 10 . Each material of grade 4 and 5 involves a text book, work book, teacher's guide as well as an audio for listening. The experimental groups were supported with supplementary materials, including short stories, supplemental reading comprehension materials, and electronic sources.

\subsection{Procedures}

The treatment was conducted over ten weeks from the beginning of October till the end of December 2019. It was carried out in two sessions a week, with a total of 20 periods excluding the pre-test/post-test sessions for each class. Firstly, the researcher obtained the consent of the Ministry of Education and Irbid District to conduct this quasi-experimental study. After that, the researcher trained the experimental group teachers to familiarize them with the strategies of differentiated instruction and how to implement the needed procedures. To indicate homogeneity between the two groups at the beginning of the study, a pre-test for grade 4 was held, and the independent sample t-test was calculated. The pre-test showed uniformity of the two groups. The students of class 5 also received the pre-test, and the t-test was calculated and found that the two levels of grade five are equivalent at the beginning of the study.

Using the data from the pre-test, the teachers formed data about experimental group students. Using the data, the teachers of the experimental groups provided instruction of differentiated learning of homogeneous grouping, leveled coaching, and various tasks in the areas of content, methodology, and outcome. However, the teachers of the control groups delivered instruction based on the one-size-fits-all method using the content of Action Pack 4 and 5 textbooks only. Students of the experimental groups were arranged into three ability groups to receive instruction based on their proficiency level. Tiered activities and tiered assignments, as well as texts with different complexities, were prepared for the various groups of the treatment group students.

The comparison group, on the other hand, received instruction without differentiation in the content, process, or product. They were taught following the one-size-fits-all method where the teacher stands in the front and deliver instruction to all students without separating teaching. To differentiate the 
content for the experimental group, the teachers and the researchers modified the reading comprehension texts from the textbook to satisfy the three levels of students. They provide different leveled-reading comprehension texts to suit them. In the process, flexible grouping was used. Gathering by readiness or homogeneous grouping was followed to satisfy the three levels of students. In the product, several product choices like written tasks, oral tasks, drawings, and posters were organized to show students' learning. However, the control group students were given the same texts of the reading comprehension and the same questions to all students. The researchers administered the post-tests for all the groups at the end of the study to determine the effectiveness of differentiated instruction on the primary level. The independent sample t-test, standard deviation, mean scores, and Cohen's d effect size were employed to find the results and interpret the findings.

\subsection{Data Analysis}

The upshots of the post-tests were analyzed using a t-test, standard deviation, mean scores, and Cohen's d effect size. The results of grade four students of the post-test were associated to their results in the pre-test. Besides, the findings of grade 5 students of the post-test were also compared to their findings of the pretest using the independent sample of t-test, effect size, mean scores, and standard deviations.

\section{Findings}

Tables 2, 3, 4, and 5 present and compare the mean, the standard deviation, $\mathrm{t}$ test, and the effect size of the students' achieved scores in the exams of groups. Table 2 explains the results of the pre-test. Table 3 compares the post-test results. Table 4 compares the results of grade 4 of both tests, the pre-test and the posttest, and Table 5 compares the effects of both groups of grade 5 on both tests.

Table 2: T-test results of the experimental and control groups on the pre-test

\begin{tabular}{|l|l|l|l|l|l|l|l|}
\hline Test & Level & Group & $\mathbf{N}$ & Mean & $\begin{array}{l}\text { Std. } \\
\text { Deviation }\end{array}$ & $\mathbf{t}$ & Sig. \\
\hline \multirow{3}{*}{$\begin{array}{c}\text { Pre- } \\
\text { test }\end{array}$} & $\begin{array}{l}\text { Grade } \\
\mathbf{4}\end{array}$ & control & 29 & 18.4 & 7.25 & \multirow{2}{*}{0.41353} & \\
\cline { 2 - 9 } & $\mathbf{5}$ & experimental & 30 & 18.82 & 7.59 & 0.680 \\
\cline { 2 - 9 } & $\mathbf{5}$ & expentrimental & 30 & 18.20 & 7.53 & 0.545 & 0.724 \\
\hline
\end{tabular}

Table 3: T-test results of the experimental and control groups on the post-test

\begin{tabular}{|c|c|c|c|c|c|c|c|c|}
\hline Test & Level & Group & $\mathbf{N}$ & Mean & $\begin{array}{l}\text { Std. } \\
\text { Deviatio } \\
\text { n }\end{array}$ & $t$ & Sig. & $\begin{array}{l}\text { Effect- } \\
\text { size } \\
\text { Cohen' } \\
\text { s d }\end{array}$ \\
\hline \multirow{4}{*}{$\begin{array}{c}\text { post- } \\
\text { test }\end{array}$} & \multirow{2}{*}{$\begin{array}{l}\text { Grade } \\
4\end{array}$} & control & 29 & 18.67 & 7.09 & \multirow[b]{2}{*}{8.65} & \multirow[b]{2}{*}{$.0001^{*}$} & \multirow[t]{2}{*}{2.23} \\
\hline & & $\begin{array}{l}\text { experimenta } \\
1\end{array}$ & 30 & 33.13 & 5.79 & & & \\
\hline & \multirow{2}{*}{$\begin{array}{l}\text { Grade } \\
5\end{array}$} & control & 29 & 18.53 & 7.02 & \multirow[b]{2}{*}{10.83} & \multirow[b]{2}{*}{$.0001^{*}$} & \multirow[t]{2}{*}{2.79} \\
\hline & & $\begin{array}{l}\text { experimenta } \\
1\end{array}$ & 30 & 34.87 & 5.24 & & & \\
\hline
\end{tabular}


Table 4: T-test and effect-size results for grade 4 students on the pre and post-test for each group

\begin{tabular}{|c|c|c|c|c|c|c|c|}
\hline Grade 4 & Test & DF & Mean & $\begin{array}{l}\text { ST. } \\
\text { Deviation }\end{array}$ & $\mathbf{t}$ & Sig. & $\begin{array}{l}\text { Effect-size } \\
\text { Cohen's } d\end{array}$ \\
\hline \multirow[t]{2}{*}{ Control } & pre & \multirow[t]{2}{*}{28} & 18.4 & 7.25 & \multirow[t]{2}{*}{0.144} & \multirow{2}{*}{.8859} & \multirow{2}{*}{0.037} \\
\hline & post & & 18.67 & 7.09 & & & \\
\hline \multirow[t]{2}{*}{ Experimental } & pre & 29 & 18.82 & 7.20 & \multirow{2}{*}{8.69} & \multirow{2}{*}{$.0001^{*}$} & \multirow{2}{*}{2.18} \\
\hline & post & & 33.13 & 5.79 & & & \\
\hline
\end{tabular}

Table 5: T-test and effect-size results for grade 5 students on the Pre and Post-test for each group

\begin{tabular}{|l|l|l|l|l|l|l|l|}
\hline Grade 5 & Test & DF & Mean & $\begin{array}{l}\text { ST. } \\
\text { Deviation }\end{array}$ & $\mathbf{t}$ & Sig. & $\begin{array}{l}\text { Effect-size } \\
\text { Cohen's } d\end{array}$ \\
\hline Control & pre & \multirow{2}{*}{28} & 18.20 & 7.53 & \multirow{2}{*}{0.285} & .77618 & 0.089 \\
\cline { 2 - 5 } & post & 28.53 & 7.02 & & & \\
\hline \multirow{2}{*}{ Experimental } & pre & 29 & 18.07 & 7.20 & \multirow{2}{*}{10.41} & $.0001^{*}$ & 2.666 \\
\cline { 2 - 4 } & post & & 34.87 & 5.24 & & \\
\hline
\end{tabular}

\section{Discussion}

Two classes of grade 4 and two classes of grade 5 were selected to examine the effectiveness of the strategies of differentiated learning on English reading comprehension attainment at primary level in Jordan. Gender did not affect the results of the study since all respondents are male students. As indicated in Table 2, the average score of the control group in level 4 was 18.4 on the pre-test and was 18.82 for the experimental group. The descriptive statistic independent sample, t-test, was calculated to show whether the difference is statistically significant. The t-test was 0.41 and $p=0.680$, which is above the significant level $\mathrm{P}<0.05$. So, the alteration between the two groups is insignificant at $\mathrm{P}<0.05$, which indicates that both the research groups of grade four are homogeneous at the beginning of the treatment. For level five, the mean score of the control group was 18.20 and 18.07 for the experimental group. The researcher used the independent sample t-test to show if the dissimilarity in the two mean scores is significant. The $t$-test value was 0.545 , and the significance was $p=0.724$. So, $\mathrm{P}>0.05$, indicates that the difference is insignificance, and both groups of level five are also homogeneous at the onset of the treatment.

After implementing the treatment, the post-tests were held to show the difference in reading comprehension accomplishment. As indicated in Table 3, the mean score of the control group of grade 4 , who received instruction on the one-size-fits-all method, was 18.67. In contrast, the mean scores of the treatment group, which followed differentiated education strategies, were 33.13. The mean scores show that the treatment group outperformed those of the comparison group. The independent sample t-test was measured to distinguish if the difference is meaningful. T-test is the most suitable statistical analysis for the two homogeneous groups as in this study. T-value was 8.65 (sig. $=0.0001$ ) indicates that the difference is statistically noteworthy. Therefore, the null 
hypothesis is rejected, and the alternative hypothesis is adopted because of the $\mathrm{P}<0.05$ level of significance. So, it is safe to say that using differentiated instruction strategies was considered useful in developing level four reading comprehension achievements. Moreover, the post-test mean score for level five's control group was 18.53 and 34.87 for the experimental group. Level five experimental group mean score outweighed the control group's mean scores. The t-test value was 10.83 and $\mathrm{P}=0.0001$, which is less than the level of significance $\mathrm{P}<0.05$, indicating that the variance in the mean scores was statistically noteworthy. The null hypothesis is rejected, and the difference between the two groups is related to using differentiated instruction. Differentiated instruction also helped to develop grade 5 reading comprehension achievements.

To compare the results of each level, as shown in Table 4, the level 4 control group gained no statistically significant variance between the pre and post-test. In other words, the traditional method, which was the one-size-fits-all, did not affect students' English reading comprehension achievement. The mean score for the pre-test was 18.4 and was 18.67 in the post-test. The variance between the two tests was statistically insignificant; the t-value was 0.144 , and the P-value was 0.8859, $\mathrm{P}>0.05$, which is bigger than the level of significance $\mathrm{P}<0.05$. Compared to the treatment group, the pre-test mean score was 18.82 and rose to 33.13 on the post-test. The difference is statistically significant at $\mathrm{P}<0.05$. The $\mathrm{t}$ value was found to be 8.69 at sig=0.0001, so $\mathrm{P}<0.05$. Therefore, differentiated instruction affected grade 4 students' reading comprehension achievement positively. For grade 5, as shown in Table 5, the control group gained no progress between the pre-test and post-tests. The pre-test's mean score was 18.20 and became 18.53 on the post-test. The variance is insignificant at $P<0.05$. The traditional method did not help students' English reading comprehension achievement improved significantly. However, the experimental group prepared following differentiated learning strategies was utterly different. The pre-test mean score was 18.07 and rose to reach 34.87 on the post-test. The difference is statistically considerable at $\mathrm{P}<0.05$. The $\mathrm{t}$-value was 10.41 , and $\mathrm{P}$ was 0.0001, which is below $\mathrm{P}<0.05$. Therefore, differentiated instruction effectively improved level five reading comprehension achievement.

A remarkable notice is indicated from the findings of the results of grades 4 and 5 experimental groups related to standard deviation. As presented in Table 4, the standard deviation of the grade 4 experimental group was 7.20 before the treatment, and reduced to 5.79 after the experiment which indicates that modifying education did not only improve reading comprehension achievement for level 4 but also reduced students' diversity and changed the mixed-ability classroom to be more homogeneous. However, the standard deviation for the control group was 7.25 and became 7.09. Nearly no change happened to reduce classroom diversity in the control group, which was taught traditionally. Moreover, level five students' experimental group standard deviation, as shown in Table 5, was 7.20 and reduced to 5.24 after the experiment. Like level 4, modified learning helped reduce classroom diversity and turned it to be more homogeneous for level 5. However, the level five control group's standard deviation nearly stayed relatively unchanged; it was 7.53 and became 7.02, 
which indicated that the traditional way does not help reduce classroom diversity.

Moreover, the effect size was highlighted. Cohen's d formula was used to figure out the variance between the two means of level four and the two groups of level five. Cohen explained that the value of 0.2 expresses a small effect size, and 0.5 illustrates a medium effect size, and above 0.8 indicates a large one (Sullivan and Feinn, 2012). The effect size presented in Table 4 for grade 4 was 2.18, so it is a large effect size for differentiated instruction for level four. As indicated in table 5, the effect size for class five was 2.666 , which is also a large effect size, and suggests that implanting differentiated instruction was effective in increasing reading comprehension achievement for both types four and five. However, for the control groups of grades 4 and 5, the effect size was 0.037 and 0.089 , respectively, which showed a petite effect size on both classes to show that traditional teaching did not affect levels 4 and 5 English reading comprehension achievement in Jordan.

The findings of the research are in line with Shaunessy-Dedrick, Evan, Ferron, and Lindo's (2015) findings in that differentiated instruction improved grade 4 students' reading comprehension achievement. The results are also consistent with Yousefi and Bonyadi's (2016), Jefferson, Grant, and Sander's (2017), Altin, and Saracaloğlu's (2018), Davidsen's (2018) and Mavido and Kakana (2019)'s whose findings indicated the effectiveness of differentiated learning on students' reading comprehension attainment. Moreover, the results of the study were also comparable to Magableh \& Abdullah's (2019) results in that differentiated instruction develops reading comprehension achievement and reduced classroom diversity to be more homogeneous.

\section{Conclusion}

Data analysis revealed that distinguished learning had a positive impact on English reading comprehension achievement in levels 4 and 5 in Jordan. Distinction significantly developed students' performance in reading comprehension at the primary levels. Besides, the results of the study showed that implementing differentiated teaching in a mixed-ability classroom reduced students' diversity to be more homogeneous. At the primary level, students do not know how to read, learn, and do not know how to complete assignments. So, implementing differentiated instruction strategies like differentiated content, tiered activities, and tiered assignments contributed to their accomplishment. It is a fact that students in one single and mixed-ability classroom are not the same. They have different interests, starting points, attitudes, bits of intelligence, and various skills. So, differentiated instruction can help reduce this classroom diversity by separating the content, process, and product. This study mainly revealed that implementing modified education on primary students can lead to improving their reading comprehension development. Differentiated instruction strategies, as shown in this research, have a sizable effect size on EFL students' English reading comprehension learning, unlike the one-size-fits-all way, which has a minimal effect size, and did not reduce students' diversity. Primary-level students do not know how to learn independently, so it is the teachers' methods 
that lead them toward gaining their goals. The primary students still depend heavily on the different techniques their teachers are following. Differentiated instruction helped improve the primary students' reading comprehension in Jordan. The study is limited due to the small sample, and to the short duration of the treatment. Moreover, the procedure is limited because only one instrument was used for data collection in which the quantitative method is used. It would be better to have more schools from different districts with a more extended period of implementation.

\section{Declaration of Conflicting Interests}

The authors declared no possible conflicts of interest concerning the research, production, and or publication of this article. Any organization did not fund this research.

\section{Acknowledgment}

The researchers would like to thank the board of education and the teachers involved for their support during the research.

\section{References}

Al Harafsheh, A. (2016). A study of social factors affecting English language reading habits of Jordanian English as a foreign language (EFL) students in selected schools in Al Mafraq Directorate. Unpublished Doctoral thesis. Universiti Sains Malaysia, Malaysia.

Aliakbari, M., \& Haghighi, J. K. (2014). On the effectiveness of differentiated instruction in the enhancement of Iranian learners reading comprehension in separate gender education. Procedia-Social and Behavioral Sciences, 98, 182-189. https:// doi.org/10.1016/j.sbspro.2014.03.405

AlShoura, H. (2017). Sense of self-efficacy and attitudes towards the implementation of inclusive education for students with learning disabilities in Jordan. Unpublished Doctoral thesis. Universiti Sains Malaysia, Malaysia.

Altin, M., \& Saracaloğlu, A. S. (2018). Effect of reading comprehension instruction enriched with cultural materials on English learning. Cogent Education, 5(1). https://doi.org/10.1080/2331186x.2018.1475589

Anstee, P. (2014). Differentiation pocketbook. Management Pocketbooks. Teacher's pocketbooks. Hampshire, UK.

Bondie, R. S., Dahnke, C., \& Zusho, A. (2019). How does changing "one-size-fits-all" to differentiated instruction affect teaching? Review of Research in Education, 43(1), 336-362.

Corley, M. A. (2005). Differentiated instruction: Adjusting to the needs of all learners. Focus on Basics, 7, 13-16. https://doi.org/10.3102/0091732×18821130

Creswell, J. W. (2012). Educational research: Planning, conducting, and evaluating quantitative and qualitative research.

Davidsen, D. L. (2018). Effect of Differentiated Instruction on Reading Comprehension of Third Graders. ProQuest LLC, Ed.D. Dissertation, Walden University, ERIC ED592186, ISBN: 978-0-4386-0735-4.

Förster, N., Kawohl, E., \& Souvignier, E. (2018). Short-and long-term effects of assessment-based differentiated reading instruction in general education on reading fluency and reading comprehension. Learning and Instruction, 56, 98-109. https:// doi.org/10.1016/j.learninstruc.2018.04.009 
Graham, C. R., Borup, J., Pulham, E., \& Larsen, R. (2019). K-12 Blended teaching readiness: Model and instrument development. Journal of Research on Technology in Education, 1-18. https:// doi.org/10.1080/15391523.2019.1586601

Hawkins, J., Jones, S. J., \& Santi, K. L. (2019). Diverse ability levels: Differentiating instruction to teach to all learners. Empathic teaching. Promoting Social Justice in the Contemporary Classroom, 75. https:// doi.org/10.1080/00940771.2002.11494669

Heacox, D. (2018). Making differentiation a habit: How to ensure success in academically diverse classrooms. Free Spirit Publishing. https:// doi.org/10.1002/t1.20254

Ismail, S., \& Al Allaq, K. (2019). The nature of cooperative learning and differentiated instruction practices in English classes. SAGE Open, 9(2). https://doi.org/10.1177/2158244019856450

Jefferson, R. E., Grant, C. E., \& Sander, J. B. (2017). Effects of tier I differentiation and reading intervention on reading fluency, comprehension, and high stakes measures. Reading Psychology, 38(1), 97-124. https:// doi.org/10.1080/02702711.2016.1235648

Kassem, H. M. (2020). The effect of collaborative versus individual strategic reading on college EFL learners' reading comprehension and self-efficacy. Asian EFL Journal, 24(2).

Kent, A. (2005). Early childhood educators and literacy leaders: Powerful partners. Reading Improvement, 42(4), 238-244.

Kotob, M. M., \& Abadi, M. A. (2019). The Influence of differentiated instruction on academic achievement of students in mixed-ability classrooms. International Linguistics Research, 2(2), p8-p8. https://doi.org/10.30560/ilr.v2n2p8

Magableh. I. \& Abdullah. A. (2019). The effect of differentiated instruction on developing students' reading comprehension achievement. International Journal of Management and Applied Science (IJMAS), 5 (2), 48-53.

Malacapay, M. C. (2019). Differentiated instruction in relation to pupils' learning style. International Journal of Instruction, 12(4). https://doi.org/10.29333/iji.2019.12440a

Mavidou, A., \& Kakana, D. (2019). Differentiated instruction in practice: Curriculum adjustments in kindergarten. Creative Education, 10, 535-554. https://doi.org/10.4236/ce.2019.103039

Mulder, Q. (2014). The effect of differentiated instruction on student mathematics achievement in primary school classrooms (Master's thesis, University of Twente).

Niño Santisteban, L. (2014). The Effects of differentiated instruction on the literacy process of learners with interrupted schooling. GIST Education and Learning Research Journal, 9, 31-49.

Pallant, J. (2005). SPSS survival manual: A step by step guide to data analysis using SPSS for Windows (version 12) (2nd ed.). New South Wales: Allen \& Unwin.

Pastein, L. (2017). Differentiated Instruction in Literacy and Allowing Self-Selected Texts for Student Reading Engagement.

Said, M., \& Ehsan, N. (2019). The Effects of Differentiated Instruction on Students' Language Attitude and Critical Thinking in an ESL Context (Doctoral dissertation, University of Sheffield).

Sebihi, A. (2016). Strategizing teaching: Differentiated teaching style and learning brain. EPRA, 4(12), 115-118.

Shaunessy-Dedrick, E., Evans, L., Ferron, J., \& Lindo, M. (2015). Effects of differentiated reading on elementary students' reading comprehension and attitudes toward reading. Gifted Child Quarterly, 59(2), 91-107. https://doi.org/10.1177/0016986214568718 
Siam, K., \& Al-Natour, M. (2016). Teacher's Differentiated Instruction Practices and Implementation Challenges for Learning Disabilities in Jordan. International Education Studies, 9(12), 167. https://doi.org/10.5539/ies.v9n12p167

Stavrou, T. E., \& Koutselini, M. (2016). Differentiation of teaching and learning: The Teachers' perspective. Universal Journal of Educational Research, 4(11). 2581-2588. https://doi.org/10.13189/ujer.2016.041111

Sullivan, G. M., \& Feinn, R. (2012). Using effect-size- or why the P-value is not enough. Journal of graduate medical education, 4(3), 279-282. https://doi.org/10.4300/jgmed-12-00156.1

Tomlinson, C. A. (2014). The differentiated classroom: Responding to the needs of all learners. ASCD.

Tomlinson, C. A. (2015). Teaching for excellence in academically diverse classrooms. Society, 52(3), 203-209. https://doi.org/10.1007/s12115-015-9888-0

Tomlinson, C. A. (2017). How to differentiate instruction in academically diverse classrooms. ASCD.

Tomlinson, C. \& Imbeau, M. (2010). Leading and Managing a differentiated classroom. Alexandria, VA: Association for Supervision and Curriculum Development.

Tompkins, G., Campbell, R., Green, D., \& Smith, C. (2014). Literacy for the 21st century. Pearson Australia.

Yousefi, E., \& Bonyadi, A. (2016). The Effect of differentiated instruction on reading comprehension of Iranian Rural EFL learners. Modern Journal of Language Teaching Methods, 6(1), 927. 